\title{
Heat Shock Protection against Cold Stress of Drosophila melanogaster
}

\author{
VICKY BURTON,${ }^{1}$ HERSCHEL K. MITCHELL,,${ }^{2}$ PATRICIA YOUNG,${ }^{1}$ AND NANCY S. PETERSEN ${ }^{1 *}$ \\ Department of Molecular Biology, University of Wyoming, Laramie, Wyoming 82071, ${ }^{1}$ and Biology Division, California \\ Institute of Technology, Pasadena, California $91125^{2}$
}

Received 4 January 1988/Accepted 18 April 1988

\begin{abstract}
Heat shock protein synthesis can be induced during recovery from cold treatment of Drosophila melanogaster larvae. Survival of larvae after a cold treatment is dramatically improved by a mild heat shock just before the cold shock. The conditions which induce tolerance to cold are similar to those which confer tolerance to heat.
\end{abstract}

Heat shock proteins are a group of proteins which are universally expressed in response to heat, heavy metals, and a variety of chemical treatments $(1,5,10,11)$. The major heat shock proteins synthesized in bacteria, plants, and mammals show a high degree of sequence homology $(1,5)$. These proteins are also synthesized during some periods in normal development.

Transient resistance to killing by heat stress has been observed to be induced in many organisms by an initial exposure to a sublethal heat treatment $(2,7,11)$. We have shown that conditions which induce thermotolerance in Drosophila melanogaster also induce the synthesis of heat shock proteins (7), and this correlation has been repeated many times in a variety of systems $(1,5)$. Because of this and the universality of the response, it has been suggested that heat shock proteins play a role in protecting cells from damage caused by these stresses. The precise function of the heat shock proteins as well their role in stress protection are still uncertain.

We show here that heat shock proteins are synthesized during recovery from prolonged exposure to cold in the absence of heat shock and that a mild heat treatment of the same kind which protects against death from heat shock also prevents death from exposure to cold.

Induction of heat shock proteins by cold treatment. Drosophila larvae recovering from cold treatments of more than 8 $\mathrm{h}$ at $0^{\circ} \mathrm{C}$ synthesized the same set of heat shock or stress proteins that are made in response to heat shock $(7,9,12)$. Figure 1 shows the proteins synthesized in larval salivary glands during recovery from $14 \mathrm{~h}$ at $0^{\circ} \mathrm{C}$. Salivary glands were dissected from cold-shocked larvae that had been allowed to recover for $0,10,20,30$, or $40 \mathrm{~min}$ at $25^{\circ} \mathrm{C}$. The salivary glands were labeled for $30 \mathrm{~min}$ with $\left[{ }^{35} \mathrm{~S}\right]$ methionine, and the proteins were separated on sodium dodecyl sulfate-polyacrylamide gels as described previously (8). An untreated $25^{\circ} \mathrm{C}$ control is shown in Fig. 1, lane C, as is a typical heat shock pattern from animals heated to $37^{\circ} \mathrm{C}$ (lane $\mathrm{H})$. Clearly, all the major heat shock proteins appeared in the 20 -min sample. The strongest heat shock protein synthesis patterns were seen not during the $30 \mathrm{~min}$ immediately following the cold treatment, but rather when larvae were allowed to recover for 30 or $40 \mathrm{~min}$ before being labeled. This suggests that the induction of the heat shock proteins may be a response to the shift from 0 to $25^{\circ} \mathrm{C}$ rather than a response to the $0^{\circ} \mathrm{C}$ treatment itself. We are currently doing

\footnotetext{
* Corresponding author.
}

RNA blots to determine directly the levels of hsp70 mRNA present at $0^{\circ} \mathrm{C}$ and during the recovery at $25^{\circ} \mathrm{C}$.

Experiments designed to evaluate the effects of different durations of cold treatments and recovery intervals on the induction of heat shock proteins were also carried out. Exposure of 5-day-old larvae to $0^{\circ} \mathrm{C}$ for 11 to $16 \mathrm{~h}$ was optimal for induction of the 70-kilodalton protein. Longer treatments resulted in the deaths of most of the larvae. Exposure to $0^{\circ} \mathrm{C}$ for less than $8 \mathrm{~h}$ did not induce a significant heat shock response. The amount of hsp70 synthesized represents about a fivefold increase in synthesis, as determined by densitometer tracings of autoradiograms.

The induction of heat shock protein synthesis which we describe for Drosophila larval salivary glands is the strongest which has been reported in response to cold treatment. A slight induction of heat shock proteins is described after freezing and thawing of Neurospora crassa (3). In Escherichia coli grown in the cold $\left(10^{\circ} \mathrm{C}\right)$, the synthesis of new proteins is induced, but these proteins are not the same as those induced by heat shock (4).

A question raised by these experiments is why it takes 8 to $10 \mathrm{~h}$ to get a heat shock response. It could be just that all of the metabolic responses are extremely slow at this temperature or that some type of cellular damage must occur to trigger the response. Under the conditions shown, the larvae were alive after the cold treatment, but many did not survive to become flies. Certainly, there are many possible chemical changes associated with tissue damage which could trigger the heat shock response. It is even possible that a selfimposed anoxia could occur under these conditions if the larvae closed their spiracles and refused to breathe at $0^{\circ} \mathrm{C}$. One type of triggering mechanism which has been considered for induction of heat shock protein synthesis following high-temperature treatment can, however, be ruled out, and that is protein denaturation, which would be very unlikely to occur as a result of cold treatment.

Protection from cold shock. In our earlier experiments, which demonstrated protection against a high-temperature heat shock by an intermediate heat treatment, we made use of Drosophila larval viability as a criterion for tolerance (7). The same protection conditions which are effective in the enhancement of survival following heat shock also enhance survival of larvae exposed to cold conditions (Fig. 2 and 3). Protection experiments were carried out in $20-\mathrm{ml}$ scintillation vials with 504 -day-old larvae in each vial. Larvae were blotted dry on filter paper and transferred to the vials, and the vials were either pretreated by immersion in a water bath at $34^{\circ} \mathrm{C}$ or placed directly in ice-water at $0^{\circ} \mathrm{C}$. Control 


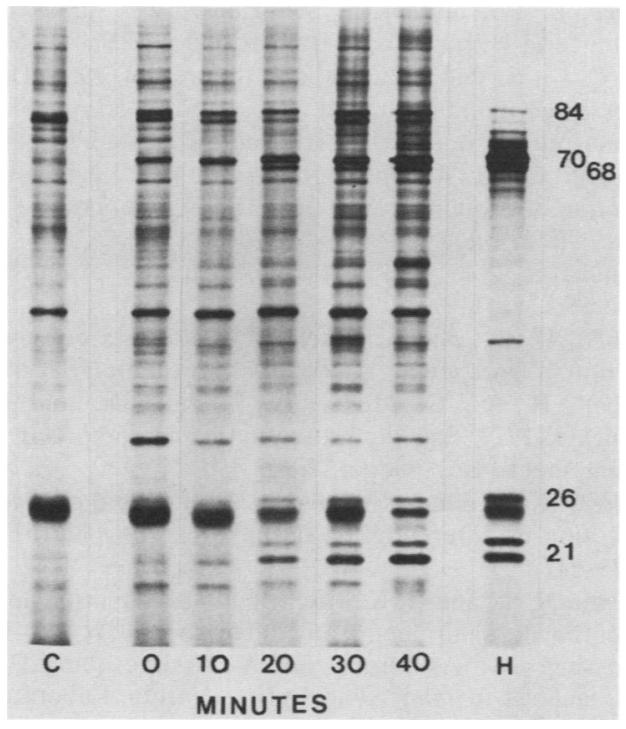

FIG. 1. Induction of heat shock proteins by cold treatments. Four-day-old larvae were exposed to $0^{\circ} \mathrm{C}$ for $14 \mathrm{~h}$ and then warmed to $25^{\circ} \mathrm{C}$. Salivary glands were dissected and labeled for $30 \mathrm{~min}$ with $\left[{ }^{35}\right.$ S]methionine. Single pairs of glands were taken after the recovery intervals indicated below the middle five lanes, dissolved in sodium dodecyl sulfate sample buffer, and subjected to electrophoresis on acrylamide gel $(6,8)$. Lane $\mathrm{C}$, Untreated $25^{\circ} \mathrm{C}$ control; lane $\mathrm{H}$, heat shock protein pattern from animals heated to $37^{\circ} \mathrm{C}$.

animals were kept in closed vials at $25^{\circ} \mathrm{C}$. Figure 2 shows the effect on survival of heating larvae for different lengths of time at $34^{\circ} \mathrm{C}$ after a $16-\mathrm{h}, 0^{\circ} \mathrm{C}$ cold shock. Larvae were photographed $8 \mathrm{~h}$ after the cold treatment. Under these conditions, dead larvae turn black because of phenol oxidase activation, while the live larvae remain white and burrow into the food or crawl up on the walls of the vials, where they pupate. In this particular experiment, all of the larvae in the vial which had not been heated to $34^{\circ} \mathrm{C}$ died eventually, but most of those in the vial which had spent 80 min at $34^{\circ} \mathrm{C}$ survived to pupation. (The 4-day-old larvae used in these experiments were more heat sensitive than the 5-day-old larvae used in the experiments described in Fig. 1.)

More quantitative data are given in Fig. 3. In these experiments, the cold treatment was reduced to $5 \mathrm{~h}$ at $0^{\circ} \mathrm{C}$ to
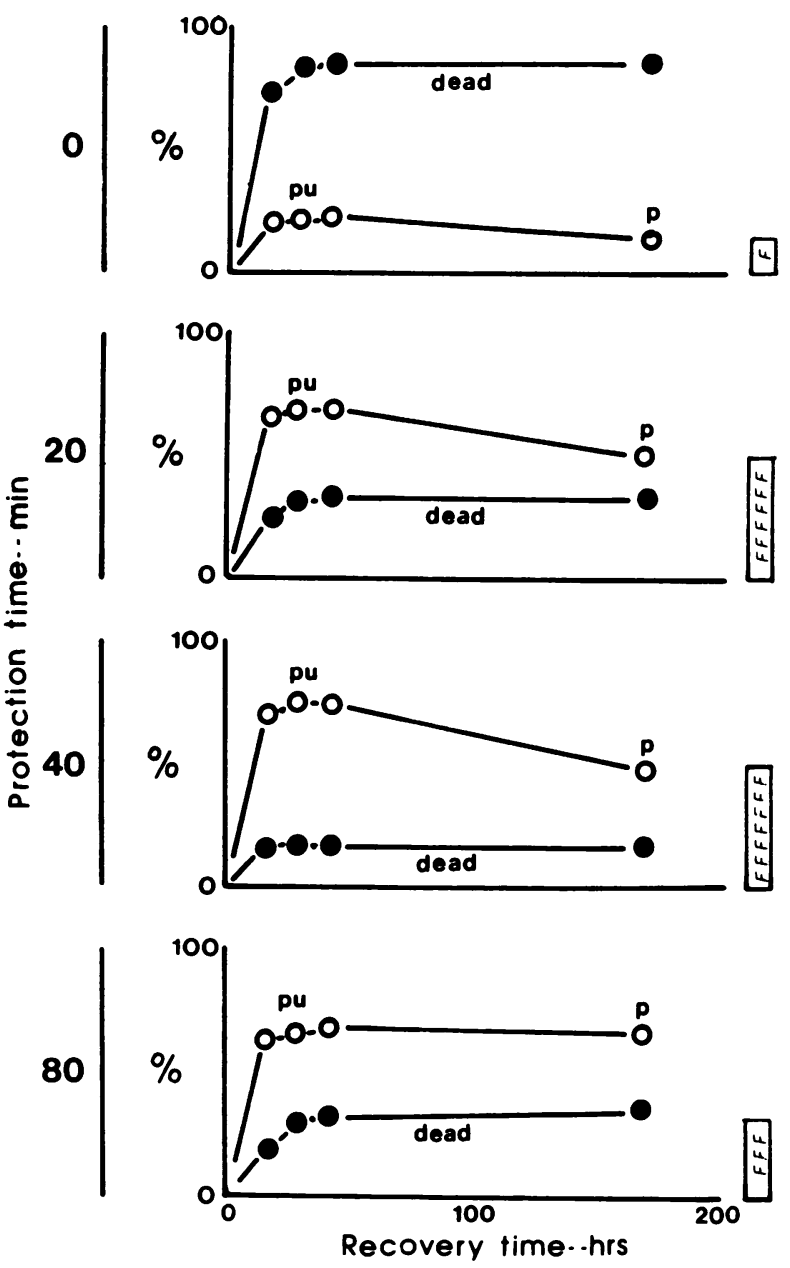

FIG. 3. Cold protection and survival. Numbers at left indicate times for which larvae ( 100 per vial) were heated at $34^{\circ} \mathrm{C}$. They were then cooled to $0^{\circ} \mathrm{C}$ in ice for $5 \mathrm{~h}$ and transferred to food vials at $25^{\circ} \mathrm{C}$. The percentage of the larvae that died as a result of the warm and cold treatments $(O)$ and the percentage which survived $(O)$ and developed to puparia (pu) and subsequently to pupae (p) are shown. The bars at the right show the percentage of the larvae that emerged as adult flies $(\mathrm{F})$.

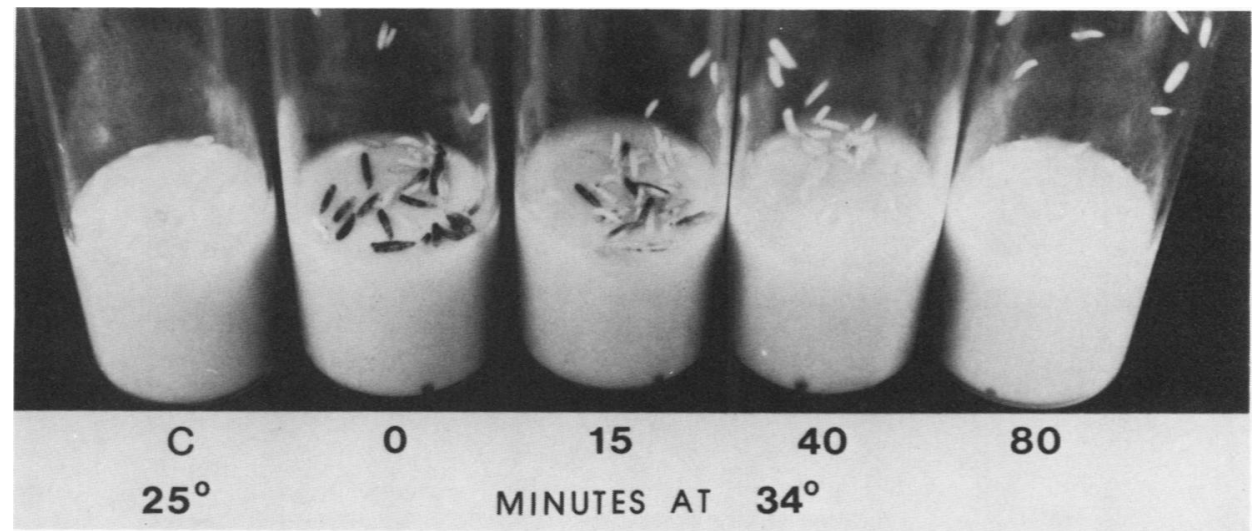

FIG. 2. Cold protection. The photograph was taken $8 \mathrm{~h}$ after larvae were removed from the ice and transferred to food-containing vials at $24^{\circ} \mathrm{C}$. The black larvae are those which died during this period as a result of the warm and cold treatments. The control (vial C) animals were kept at $25^{\circ} \mathrm{C}$ during the entire period of the experiment. 
permit both better survival with no pretreatment and significant survival to adulthood. It is worthy of note here that a good deal of protection is provided even by a 20-min pretreatment and that survival to adulthood becomes reduced by pretreatments longer than $40 \mathrm{~min}$.

We have shown that cold treatment can induce the synthesis of heat shock proteins and that a mild heat shock which induces synthesis of heat shock proteins can enhance survival rates following cold treatment. Together, these results suggest a role for heat shock proteins in recovery from cold shock. This implication should be taken with some caution. In the only other case of which we are aware in which heating has been shown to protect from cold (in the case of freezing injury to $N$. crassa [3]), the possible role of heat shock proteins was discounted because the protective heat treatment worked just as well in the presence of cycloheximide. The $N$. crassa experiments are different from those reported in this paper in that the injury was caused by freezing and thawing. The Drosophila larvae were never frozen in our experiments. Nevertheless, it is not possible to conclude from these data whether it is the synthesis of heat shock proteins or some other change which occurs at $34^{\circ} \mathrm{C}$ which confers cold resistance on the larvae.

This work was supported in part by a National Science Foundation-EPSCoRE grant to the University of Wyoming and by Public Health Service grant GM25966B.

\section{LITERATURE CITED}

1. Craig, E. A. 1985. The heat shock response. Crit. Rev. Biochem. 18:239-280.
2. Gerner, E. W., and M. J. Schneider. 1975. Induced thermal resistance in HeLa cells. Nature (London) 256:500-502.

3. Guy, C. L., N. Plesofsky-Vig, and R. Brambl. 1986. Heat shock protects germinating conidiospores of Neurospora crassa against freezing injury. J. Bacteriol. 167:124-129.

4. Jones, P. G., R. A. VanBogelen, and F. C. Neidhardt. 1987. Induction of proteins in response to low temperature in Escherichia coli. J. Bacteriol. 169:2092-2095.

5. Lindquist, S. 1986. The heat-shock response. Annu. Rev. Biochem. 55:1151-1191.

6. Mitchell, H. K., and A. Mitchell. 1963. Mass culture and age selection in Drosophila. Drosophila Information Service 39:135.

7. Mitchell, H. K., G. Moller, N. S. Petersen, and L. LippsSarmiento. 1979. Specific protection from phenocopy induction by heat shock. Dev. Genet. 1:181-192.

8. Mitchell, H. K., and N. S. Petersen. 1981. Rapid changes in gene expression in differentiating tissues of Drosophila. Dev. Biol. 85:233-242.

9. Petersen, N. S., and H. K. Mitchell. 1982. Induction and prevention of the multihair phenocopy in Drosophila, p. 345-352. In M. Schlessinger, M. Ashburner, and A. Tissieres (ed.), Heat shock from bacteria to man. Cold Spring Harbor Laboratory, Cold Spring Harbor New York.

10. Petersen, N. S., and H. K. Mitchell. 1985. Heat shock proteins, p. 347-366. In G. A. Kerkut and L. I. Gilbert, (ed.), Comprehensive insect physiology, biochemistry, and pharmacology, vol. X. Biochemistry. Pergamon Press, Inc., Elmsford, N.Y.

11. Schlesinger, M. J., M. Ashburner, and A. Tissieres (ed.). 1982. Heat shock from bacteria to man. Cold Spring Harbor Laboratory, Cold Spring Harbor, New York.

12. Tissieres, A., H. K. Mitchell, and U. M. Tracy. 1974. Protein synthesis in salivary glands of Drosophila melanogaster: relation to chromosome puffs. J. Mol. Biol. 84:389-398. 